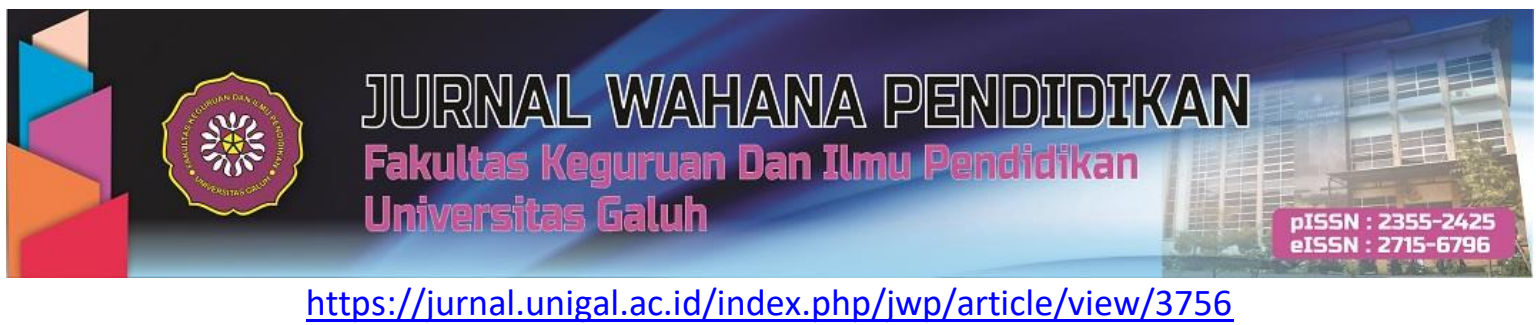

\title{
KARAKTER TOKOH AIRA DALAM NOVEL PADA SENJA YANG MEMBAWAMU PERGI KARYA BOY CANDRA DAN IMPLIKASI PEMBELAJARANNYA
}

\author{
Citra Mutiara Sari ${ }^{1}$ \\ 1 Universitas Pancasakti Tegal \\ Email: citra.citra2980@gmail.com
}

\section{ABSTRACT}

The purpose of this study is to describe the character of the character Aira in the novel In the Twilight That Takes You Away by Boy Candra and describe the implications of literary learning in high school. This study uses a qualitative method. Qualitative research methods are research that aims to find out the facts carried out for the subject of assessment, such as character, appreciation, motivation, action, holistically, as well as described in the spelling format. The characters and characters in the novel In the Twilight That Takes You Away by Boy Candra is Aira. Researchers examined the character of Aira based on the attitude of interest, desire, emotional and moral found in Aira through direct dialogue or sentences spoken by other figures about the character of Aira. There are three characters of attraction that are loving Gian, like black clothes or dark nuances, and like twilight. Then from the attitude of desire there are three characters namely wanting to get a scholarship to Japan, making peace with the past, and wanting to live life with Gian. From the emotional attitude there is one character that is still pictured in his past. Finally, the moral attitude that is mature in dealing with a thing, a woman who is smart, polite and kind, always respecting others, and caring about her grandmother's feelings.

Keywords: Characters, novels, learning implications.

\section{ABSTRAK}

Tujuan dari penelitian ini adalah untuk mendeskripsikan karakter tokoh Aira dalam novel Pada Senja yang Membawamu Pergi karya Boy Candra dan mendeskripsikan implikasi pembelajaran sastra di SMA. Penelitian ini menggunakan metode kualitatif. Metode penelitian kualitatif adalah penelitian yang bertujuan untuk mengetahui fakta yang dilakukan bagi subjek pengkajian, seperti karakter, apresiasi, motivasi, tindakan, secara holistic, serta diuraikan pada format ejaan. Tokoh dan penokohan dalam novel Pada Senja yang Membawamu Pergi karya Boy Candra adalah Aira. Peneliti menelaah karakter tokoh Aira berdasarkan sikap ketertarikan, keinginan, emosional dan bermoral yang terdapat pada Aira melalui dialog langsung maupun kalimat yang diucapkan oleh tokoh lain tentang karakter Aira. Terdapat tiga karakter dari sikap ketertarikan yaitu mencintai Gian, menyukai pakaian berwarna hitam atau berunuansa gelap, dan menyukai senja. Kemudian dari sikap keinginan terdapat tiga karakter yaitu ingin mendapatkan beasiswa ke Jepang, berdamai dengan masa lalu, dan ingin menjalani hidup bersama Gian. Dari sikap emosional terdapat satu karakter yaitu masih terbayang masa lalunya. Terakhir dari sikap bermoral yaitu dewasa dalam menyikapi suatu hal, wanita yang cerdas, sopan dan baik hati, selalu menghargai orang lain, dan peduli dengan perasaan Neneknya.

Kata Kunci: Karakter Tokoh, novel, implikasi pembelajaran.

Cara sitasi:

Sari,C. M. (2020). Karakter Tokoh Aira dalam Novel pada Senja yang Membawamu Pergi Karya Boy Candra dan Implikasi Pembelajarannya. Jurnal Wahana Pendidikan, 7 (2), 193-200. 


\section{PENDAHULUAN}

Menurut Teeuw (2013: 20) kata sastra dalam bahasa Indonesia berasal dari bahasa Sanskerta, yaitu berasal dari akar kata yang artinya mengarahkan, mengajar, memberi petunjuk, dan instruksi'. Akhirannya, biasanya menunjukkan 'alat'. Jadi, sastra adalah alat untuk mengajar, memberi petunjuk atau instruksi. Suatu pengungkapan pendapat serta isi hati penulis dengan format catatan maupun lisan, dengan cara mengamati kehidupan disekitar sebagai wadah penyampaian ide-ide. Termasuk karya sastra adalah puisi, prosa fiksi, dan drama. Sedangkan sastra menurut Suharianto (2009:3) merupakan pengejawantahan pikiran dan perasaan pengarang dalam bentuk untaian kalimat setelah bersentuhan secara mesra dengan kehidupan sekeliling, baik secara langsung maupun tidak langsung. Dengan sentuhan kehidupan secara langsung dimaksudkan ialah kehidupan yang dialami pengarang secara badaniah, baik secara nyata dialami dan dirasakan sendiri, maupun dilihat atau didengar dari pengalaman orang lain.

Di dalam Kamus Istilah Sastra, Sudjiman (1986: 52) menyebutkan bahwa novel adalah prosa rekaan yang panjang, yang menyuguhkan tokoh-tokoh dan menampilkan serangkaian peristiwa dan latar secara tersusun. Novel adalah prosa rekaan yang panjang dan bukan prosa rekaan yang pendek, karena termasuk prosa rekaan yang pendek adalah cerita pendek atau cerpen. Novel menyuguhkan tokoh-tokoh, artinya adalah bahwa di dalam novel terdapat sejumlah tokoh. Sementara itu, novel menampilkan serangkaian peristiwa. Artinya adalah dalam novel terdapat pencabangan cerita yang menjadikan ceritanya panjang. prosa-rekaan panjang yang berisi buah pikiran pengarang yang sengaja disusun untuk menyatakan ide-idenya, diolah penulis yang dihubungkan dengan kejadian atau peristiwa di sekelilingnya. Bisa juga merupakan pengalaman penulis, pola penulisan mengalir secara bebas yang tidak terikat oleh kaidah seperti terdapat pada novel maupun puisi. Peneliti ini bermanfaat dalam pengembangan ilmu sastra, baik bagi teori sastra, sejarah sastra, maupun kritik sastra.

Nampaknya istilah "sastra" lebih tepat digunakan pada seni sastra, yakni tulisan bagai karangan kreatif. Terdapat beberapa persoalan saat memakai kata tersebut. Namun dengan kata lain, yakni "fiksi" (fiction) dan "puisi" (poetry), terlampau minim pemahamannya. Padahal kata "sastra imajinatif" (imaginative literature) dan belles letters dari bahasa Prancis, yang bermakna catatan yang menarik serta beradab. Paling tidak menyamai pemahaman etimologi kata susastra, tetapi kurang tepat serta dapat mendukung pemahanan yang tidak valid. Istilah literature mengacu atas karangan tulisan maupun cetak. Sedangkan, sastra semestinya juga meliputi sastra lisan. Pada perihal ini, istilah Jerman Workunst maupun istilah Rusia slovesnost makin besar capaiannya serta makin dimengerti (Wellek dan Warren,1989).

Novel adalah karangan prosa-fiksi. Prosa berarti karangan bebas, tidak terikat, sedangkan fiksi berarti rekaan, bukan berisi kenyataan. Novel merupakan karangan khayalan yang dibangun berdasarkan beberapa unsur intrinsik. Unsur intrinsik dibuat penulis serta dibuat seperti pada kehidupan sebenarnya komplit dengan kejadian-kejadian di dalamnya, sehingga terlihat nyata. Unsur intrinsik yang mengakibatkan karangan sastra novel ada. Boy Candra adalah penulis novel yang memiliki keunikan sendiri dengan menggunakan gaya bahasa puitis dan dipenuhi dengan quote-quote yang mewakili setiap bab. Novel yang berjudul Pada Senja yang Membawamu Pergi karya Boy Candra mengusung konsep yang sering dialami kebanyakan kaum remaja seperti percintaan, persahabatan, tentang meninggalkan dan ditinggalkan.

Novel ini menceritakan tentang kisah Gian, Putri, Andre, Randi dan Aira dalam usaha meraih mimpi dalam kisah cinta mereka. Karakter dan masalah yang dialami setiap tokohnya pun berbeda-beda. Gian yang jatuh cinta dan patah hati karena perbedaan status dengan pacarnya, Putri yang memendam rasa cinta pada pria idamannya, Andre yang sibuk dengan laptopnya namun memendam rasa cinta kepada Putri, dan Randi yang suka bergonta ganti pasangan. Aira adalah gadis manis yang dibilang cukup misterius yang hadir dalam kehidupan Gian melalui pertemuan yang tidak disangka-sangka. Sifatnya yang misterius, kadang melekat tetapi kadang Aira membentengi ruang dengan Gian. Meskipun Aira bukan tokoh utama dalam novel tersebut, namun 
kisah Aira yang digambarkan dalam novel tersebut memiliki jiwa yang berani mengambil keputusan di saat Aira telah menemukan cinta sejatinya, dia malah memilih meninggalkannya demi melanjutkan studinya di luar negeri yang sudah lama dia impikan. Sejalan dengan itu, penulis terdorong untuk meneliti aspek karakter yang ada dalam novel Pada Senja yang Membawamu Pergi karya Boy Candra. Untuk itu, penulis memberi judul penelitian ini "Karakter Tokoh Aira dalam Novel Pada Senja yang Membawamu Pergi karya Boy Candra dan Implikasinya dalam Pembelajaran Sastra di SMA". Rumusan masalah pada penelitian ini adalah bagaimana karakter tokoh Aira pada novel dan bagaimana implikasi pembelajaran sastra di SMA. Tujuan penelitiannya untuk mendeskripsikan karakter tokoh Aira dalam novel Pada Senja yang Membawamu Pergi karya Boy Candra, mendeskripsikan implikasi pembelajaran sastra di SMA.

\section{METODE PENELITIAN}

Penelitian ini dilakukan dengan menggunakan metode kualitatif. Menurut Moleong (2004) metode penelitian kualitatif adalah penelitian yang bertujuan untuk mengetahui fakta yang dilakukan bagi subjek pengkajian, seperti karakter, apresiasi, motivasi, tindakan, secara holistic, serta diuraikan pada format ejaan. Penelitian ini sendiri akan dikaji melalui pendekatan objektif. Karena pendekatan objektif tidak lepas dari hubungan pengarang dan karyanya. Karya sastra tak hanya hadir dari awang-awang, tapi ada penciptanya. Pencipta karya sastra atau pengarang sangat penting kedudukannya dalam karya sastra. Di sini, pengarang ditempatkan sebagai subjek yang menciptakan, sedangkan karya merupakan objek dari yang menciptakan. Pendekatan objektif dalam penelitian ini digunakan untuk menganalisis karakter tokoh Aira dalam novel Pada Senja yang Membawamu Pergi karya Boy Candra.

Prosedur penelitian dilakukan dengan segenap tindakan yang akan dilakukan meliputi tahap pra-penelitian disebut juga sebelum penelitian. Pada tahap ini peneliti melakukan studi pendahuluan dan penyusunan proposal penelitian untuk merumuskan permasalahan penelitian dan tujuannya. Selanjutnya pada tahap penelitian, peneliti melakukan pengumpulan data, analisis data, dan penyusunan data. Peneliti menggunakan pengamatan dengan cermat untuk mengumpulkan datadata, menyeleksi data-data serta dianalisis sesuai dengan judul penelitian. pasca-penelitian adalah melakukan penyimpulan dan penyusunan laporan penelitian. Selain itu, pada tahap pasca-penelitian dilakukan pembacaan ulang berkali-kali.

Sumber data pada penelitian ini yaitu novel Pada Senja yang Membawamu Pergi karya Boy Candra cetakan Gagas Media, cetakan pertama Juli 2016. Penelitian ini fokus pada karakter tokoh Aira yang terdapat pada novel tersebut. Unsur-unsur penokohan dijadikan pusat permasalahan dalam novel tersebut. Menurut Sugiyono (2012) teknik pengumpulan data adalah langkah yang tepat untuk melakukan pengkajian, yang bertujuan untuk memperoleh data yang memadai. Dengan menentukan alat pengumpulan data yang tepat dan sesuai, maka data yang diperoleh akan lebih akurat dan lengkap untuk diolah dan dianalisis. Jadi, dalam penelitian ini teknik pengumpulan datanya penulis menggunakan teknik baca, simak, serta teknik catat. Dengan cara membaca objek karya sastra perlu dilakukan sesering dan sebanyak mungkin bertujuan untuk memahami secara keseluruhan unsur karya sastra pada novel tersebut secara maksimal. Teknik simak dilakukan setelah melakukan teknik baca, dengan menyimak novel tersebut yang akan dijadikan data-data sehingga dapat dikumpulkan pada penelitian ini. Teknik catat dilakukan dengan cara menandai intisari pada novel yang bertujuan untuk mendapatkan data tertulis yang akan dipakai untuk bahan analisis ke dalam data penelitian.

Teknik penyajian hasil analisis ini dilakukan dengan menggunakan berbagai sumber berbeda yang terkait dengan penelitian. Agar peneliti bisa dibaca serta dimengerti perlu adanya penyajian hasil analisis. Akhir analisis itu dibutuhkan untuk memaparkan hasil analisis dan teknik penyajian hasil analisis data memakai teknik informal. Dengan teknik tersebut hasil analisis tidak hanya disajikan secara lingual (verb) tetapi juga memperjelas kajian. 


\section{HASIL PENELITIAN DAN PEMBAHASAN}

Karakter tokoh dapat dilihat dan diuraikan dari tiap aksi yang diperankan oleh tokoh tersebut, melalui dialog dan perbuatan serta tingkah laku yang dilakukan oleh seorang tokoh. Pada bagian ini akan dideskripsikan karakter tokoh Aira dalam novel Pada Senja yang Membawamu Pergi karya Boy Candra. Berdasarkan pada sikap ketertarikan, keinginan, emosi, serta prinsip moral yang dimiliki tokoh tersebut. Berdasarkan hasil penelitian diketahui bahwa karakter tokoh Aira adalah ketertarikan, keinginan, emosional, dan bermoral. Berikut ini paparan hasil penelitiannya.

1. Ketertarikan

Aira merupakan salah satu tokoh dalam novel Pada Senja yang Membawamu Pergi karya Boy Candra yang mempunyai karakter gampang tertarik. Karakter itu diketahui melalui sejumlah kutipan berikut ini.

Matanya yang sipit, tetapi tajam, alis tebal, barisan giginya yang rapih dan putih, juga pakaian yang bernuansa gelap, membuatnya semakin nyata di kepalaku. Dia memiliki senyuman yang dingin, tetapi melekat diingatan(Candra, 2018).

Kutipan tersebut merupakan monolog dari Gian yang sedang mendeskripsikan tentang Aira, mulai dari bentuk matanya yang sipit, barisan giginya yang rapih dan bersih, sampai kesukaan Aira terhadap pakaian yang bernuansa gelap. Gian terus memuji Aira yang bersikap dingin tetapi memiliki senyuman yang melekat diingatannya.

Aku menunggunya di taman kampus. Entah kenapa, dia malah tidak mau diajak bertemu di kafe atau tempat untuk sekedar mengobrol.

"Aku lebih suka di taman kampusmu, lagi pula aku nggak tahu banyak daerah sini." (Candra, 2018).

Dengan kutipan tersebut digambarkan Aira menunjukan sikap ketertarikan pada suatu tempat, dimana tempat tersebut merupakan sebuah taman yang berada di kampus Gian, orang yang menyukai Aira pada pandangan pertama. Aira lebih suka bertemu dengan Gian di taman kampusnya karena dia juga tidak tahu banyak daerah tersebut.

"Senyuman yang manis dan menenangkan. Taman kampus ini tak begitu indah, namun cukup teduh untuk menikmati sore. Ada bunga-bunga yang sengaja ditanam sebagai hiasan. Ada pohon-pohon kecil yang berfungsi sebagai peneduh orangorang yang duduk di sekitar. Angin berhembus pelan, menerpa wajah Gian. Rambutnya tergerai, sesekali terlihat bergerak pelan. Seolah melambaikan keindahan(Candra, 2018).

Dengan kutipan tersebut digambarkan Aira yang memiliki rasa ketertarikan atau mengagumi terhadap sosok Gian yang baru dikenalnya tanpa sengaja beberapa hari yang lalu di tempat pemandian Tirta Alami. Aira menggambarkan sosok Gian dengan bahasa kiasan yang indah mengibaratkannya seperti benda-benda yang ada di sekitar lebih tepatnya di taman kampusnya Gian.

"Jangan takut, hatiku sudah memilihmu," bisiknya seolah bisa membaca kecemasanku. "Aku pasti pulang untukmu nanti(Candra, 2018).

Berdasarkan kutipan tersebut, menunjukkan sikap Aira yang sudah tertarik pada Gian dan menyakinkannya agar tidak takut untuk menunggu dirinya yang sedang berada di Jepang. Karena Aira berjanji pada Gian bahwa dia pasti akan pulang hanya untuk menemui pujaan hatinya.

2. Keinginan

Aira juga merupakan tokoh yang mempunyai banyak keinginan. Temuan bahwa Aira sebagai tokoh yang banyak keinginan itu, diketahui dari beberapa kutipan berikut.

"Sudah malam. Aku harus pulang," ucapnya. "Ya sudah. Aku antar ya, terima kasih sudah mau bertemu denganku." "Nggak usah diantar. Aku bisa pulang sendiri. Terima kasih juga untuk hari ini." Dia tersenyum(Candra, 2018). 
Kutipan tersebut, menunjukan sikap keinginannya Aira agar Gian tidak perlu mengantarnya pulang. Karena dia merasa bisa pulang sendiri dan itu sudah menjadi kebiasaannya. Akhirnya Aira meninggalkan Gian dengan senyuman manisnya. Tidak lupa Aira selalu mengucapkan terimakasih setelah bertemu dengan Gian.

Seringkali juga tiap kami ingin bertemu, Aira tidak ingin aku menjemputnya. Dia lebih suka kami janjian di suatu tempat dan bertemu di sana. Kemudian, barulah kami pergi ke tempat yang sama sekali tidak kami rencanakan sebelumnya.

"Kenapa kamu nggak mau aku jemput ke rumah?." Belajar dari pengalaman sebelumnya, aku memberanikan diri bertanya.

"Nggak enak sama Nenek."

"Nenekmu pemarah? Tidak terlihat seperti itu."

"Bukan itu masalahnya....." Aira menatap langit, di bangku Stasiun Kereta Api Tebing.

"Aku nggak mau bikin Nenek khawatir." (Candra, 2018).

Berdasarkan kutipan tersebut diketahui bahwa Aira tidak ingin membuat Neneknya khawatir karena dia diantar oleh laki-laki yang belum diperkenalkan olehnya. Mungkin karena Neneknya sudah tua dan di rumah hanya tinggal sama Kakek, Aira jadi tidak enak kalau dia mengajak teman lelakinya ke rumah Neneknya walaupun itu hanya menjemput atau mengantar sampai ke depan rumahnya sekalipun. Oleh karena itu Aira lebih suka janjian di suatu tempat dan bertemu di sana.

"Gie..., apa kamu masih merasakan sesuatu di dadamu perihal aku?" "Kamu nggak usah menjawabnya. Jika itu masih terasa, simpanlah sebaik yang kau bisa. Namun, jika kamu nggak sanggup menyimpannya, lepaskanlah pelan-pelan, biarkan ia mengalir ke mana saja ia pergi. Aku hanya ingin kamu tetap bahagia meski bukan dengan rasa yang ada di hatimu. Sekali lagi, selamat ya, Gie! Aku masih Aira yang sama untukmu. Kalau kamu kangen, tinggal surati aku saja(Candra, 2018).

Kutipan tersebut menjelaskan keinginan Aira perihal perasaan yang pernah tumbuh untuknya. Menurutnya kalau Gian sudah tidak sanggup untuk menyimpan perasaan cintanya kepada Aira, Gian bisa melepaskannya secara pelan-pelan. Biarkan perasaan ini mengalir ke mana saja ia pergi. karenanya Aira tidak ingin menjadi penghalang untuk masa depannya nanti entah mau sama siapa dia, yang Aira inginkan hanya melihat bahagia meski bukan dengan dirinya lagi. Namun, Aira tidak keberatan kalau saja Gian sedang merasakan kangen kepadanya tinggal surati saja Aira.

\section{Emosional}

Aira merupakan seorang tokoh yang suka emosional. Temuan karakter Aira yang emosional itu, diketahui dari sejumlah kutipan berikut ini.

"Halo Gie, kamu pasti kaget ya dapat surat dari aku. Baiklah, aku tidak ingin bercanda lebih banyak lagi. Aku tidak tahu apakah ini saat yang tepat atau tidak untuk mengirimkan surat kepadamu. Namun, aku rasa inilah saatnya aku harus menjelaskan semuanya. Ada hal-hal yang tidak bisa lagi kusembunyikan sendiri. Gie..., aku tidak tahu apakah ini bisa disebut cinta? Namun, satu hal yang aku rasakan. Aku selalu berusaha untuk tidak terlihat jatuh cinta padamu. Mesti pada kenyataanya saat aku sendiri, aku tidak bisa memungkiri, aku merindukanmu." (Candra, 2018).

Kutipan tersebut merupakan surat yang ditulis Aira untuk Gian. Pada surat tersebut menggambarkan Aira sedang bergelut dengan perasaan yang sebenarnya juga mencintai Gian. Namun, Aira selalu mengelak dan tidak berani mengungkapkannya karena Aira sendiri tidak yakin bahwa perasaan yang selama ini dia rasakan itu adalah perasaan cinta yang sesungguhnya. Ada emosi yang masih membekas dihidupnya bahwa dia tidak 
ingin gegabah seperti dahulu, dengan asal menerima cowok hanya karena tidak tega untuk menolaknya.

"Kamu apa kabar?" Suaraku keluar tak tertahan, terdengar parau. Dia hanya tersenyum, apa dia pikir ini lucu? Apa dia pikir, aku datang ke sini hanya untuk mendapatkan respons seperti itu. Apa dia tidak tahu kalau selama ini aku setengah mati menahan sesak didadaku. Saat rindu-rindu datang bersama ingatan dan wajahnya yang ada di kepalaku. "Sampai kapan kamu akan berdiri di situ?" tanya Aira. Aku masih saja beku di tempat aku berdiri. Entah mengapa saat ingin beranjak mendekati Aira, kakiku seolah tidak mampu melangkah. Hingga beberapa saat kemudian, aku merasakan hangat tubuhnya memeluk tubuhku. Udara yang dihasilkan hujan kini seolah lenyap dengan lingkaran lengan Aira di punggungku. "Maaf, aku terlalu banyak mengirim rindu. Hingga akhirnya kamu harus sampai di sini(Candra, 2018).

Dari kutipan tersebut diketahui terdapat emosi senang, bingung sekaligus tidak enak hati yang ditampilkan sikap Aira. Respon yang Aira tunjukkan saat pertama kali melihat Gian sudah di depan matanya, dia hanya memandangnya karena tidak tahu harus berkata apa yang jelas Aira merasa bahagia dan terharu melihat perjuangan Gian untuk bertemu dengannya di Jepang. Ternyata membuat Gian marah karena merasa Aira tidak senang kalau tidak menghargai perjuangannya yang sudah jauh-jauh datang ke Jepang hanya untuk membayar rindu yang selama ini membuat sesak di dadanya. Selang beberapa menit akhirnya Aira memberikan sinyal bahwa ia juga sangat merindukan Gian, dengan spontan Aira memeluk punggung Gian dengan tanpa sepatah katapun yang terucap pada bibirnya.

4. Bermoral

Aira merupakan seorang tokoh yang bermoral. Karakter Aira yang bermoral itu, diketahui dari sejumlah temuan yang dapat dilihat pada sejumlah kutipan berikut.

Kami berjalan menuju parkiran yang berada beberapa meter dari tempat kami berdiri. Namun, entah mengapa, aku justru senang dengan hujan kali ini. Mungkin karena ada Aira. Dia memayungiku ketika aku memindahkan motor, dan kami bertatapan sejenak. Ada jeda yang terasa sebelum akhirnya dia menyadari dan mengelakkan wajahnya(Candra, 2018).

Dari kutipan tersebut terlihat sikap Aira yang peduli dan menyayangi Gian. Secara spontan Aira memayungi Gian yang sudah dipegangnya dari tadi agar Gian tidak kehujanan atau ketetesan air hujan sekalipun. Ini adalah bentuk peduli dan perhatian Aira kepada Gian.

"Kamu nggak apa-apa, kan?" Tiba-tiba, pesan dari Aira masuk ke ponselku.

"Aku baik-baik saja." Aku membalas pesan Aira.

"Syukurlah, maaf memaksamu pulang saat masih hujan kemarin" (Candra, 2018). Kutipan tersebut menunjukkan adanya pesan singkat Aira kepada Gian, menunjukan sikap Aira yang merasa khawatir akan keadaan Gian saat ini setelah Aira memaksa mengantarnya untuk pulang saat hujan masih deras. Tidak ketinggalan dari sikap Aira adalah selalu meminta maaf jika merasa bersalah atau tidak enak hati karena telah melakukan suatu hal yang dirasa kurang sopan.

"Aku senang mendengar kabarmu akan diwisuda. Ah, kamu memang hebat, Gie! Selamat ya, akhirnya perjuanganmu nggak sia-sia. Aku turut bahagia mendengar kabar bahagiamu. Andai jarak nggak sejauh ini, aku pasti sudah datang ke acara bahagiamu itu. Tapi, sudahlah, kita memang nggak perlu berandai-andai. Karena itu hanya akan menimbulkan perasaan nggak karuan di hati (Candra, 2018).

Kutipan tersebut menggambarkan sikap Aira sebagai teman yang baik, dia turut bahagia mendengar kabar bahagia wisudanya Gian. Dia selalu memberikan dukungannya kepada Gian. Dia memuji keberhasilannya atas apa yang telah diperjuangkan Gian selama 
ini untuk menyelesaikan kuliahnya. Nampaknya dia menyesal karena tidak bisa menghadiri acara wisudanya karena terhalang oleh jarak yang terlalu jauh memisahkan mereka.

"Ini satu, Uda!" Aira membeli gelang itu, lalu membayarnya. Aku hanya menunggu. "Ini buat kamu." Tiba-tiba, dia memberikan gelang itu kepadaku. "Tatapi, aku nggak minta dibeliin." "Sudah. Simpan saja. Anggap saja ucapan terima kasihku sudah bersedia menemaniku. Lagi pula, aku sudah suka ini pada pandangan pertama, itu adalah salah satu perasaan terbaik manusia. Jangan diabaikan." (Candra, 2018).

Kutipan tersebut, menggambarkan sifat Aira yang baik hati kepada Gian, dia memberikan sebuah gelang sebagai tanda ucapan terima kasihnya karena sudah menemani ke mana pun dia ingin pergi. Walaupun Gian tidak mengatakan ingin dibelikannya, Aira membeli gelang tersebut karena keinginannya sendiri. Melihat ketulusan hatinya Aira, akhirnya Gian menerima gelang tersebut.

Tabel 1.

Karakter Tokoh

\begin{tabular}{|c|c|c|c|c|}
\hline $\begin{array}{l}\text { Nama } \\
\text { Tokoh }\end{array}$ & Sikap Ketertarikan & Keinginan & Emosional & Bermoral \\
\hline Aira & $\begin{array}{l}\text { 1. Mencintai Gian } \\
\text { 2. Menyukai } \\
\text { pakaian berwarna } \\
\text { hitam atau } \\
\text { bernuansa gelap } \\
\text { 3. Menyukai senja } \\
\text { dan hujan }\end{array}$ & $\begin{array}{ll}\text { 1. } & \text { Ingin } \\
\text { mendapatkan } \\
\text { beasiswa ke } \\
\text { Jepang } \\
\text { 2. }\end{array}$ & $\begin{array}{l}\text { 1. Masih } \\
\text { terbayang masa } \\
\text { lalu }\end{array}$ & $\begin{array}{l}\text { 1. Wanita yang } \\
\text { cerdas, sopan } \\
\text { dan baik hati } \\
\text { 2. Dewasa dalam } \\
\text { menyikapi } \\
\text { suatu hal } \\
\text { 3. Selalu } \\
\text { menghargai } \\
\text { orang lain } \\
\text { 4. Peduli dengan } \\
\text { perasaan } \\
\text { Neneknya }\end{array}$ \\
\hline
\end{tabular}

Berdasarkan hasil analisis karakter tokoh Aira yang meliputi aspek sikap ketertarikan, keinginan, emosional dan bermoral yang ada dalam novel Pada Senja yang Membawamu Pergi karya Boy Candra. Dari aspek ketertarikan Aira menyukai pakaian yang berwarna hitam atau bernuansa gelap karena menurutnya hitam adalah kekuatan bahwa yang bernuansa gelap tidak sepenuhnya menakutkan justru membuat kita tidak perlu takut sendirian. Berdasarkan aspek keinginan Aira memiliki keinginan yang sangat kuat dalam bidang pendidikan yaitu ingin mendapatkan beasiswa ke Jepang. Kemudian dari aspek emosional Aira masih terbayang-bayang oleh masa lalunya perihal percintaannya, untuk itu Aira sangat tertutup dengan lelaki yang berusaha mendekatinya. Pada aspek terakhir yaitu aspek bermoral, Aira adalah wanita yang cantik, cerdas dalam mengambil suatu keputusan dan sangat menghargai perasaan Neneknya.

Tabel 2.

Presentase Karakter Tokoh

\begin{tabular}{clcc}
\hline No. & \multicolumn{1}{c}{ Karakter Tokoh } & Data & Presentase \\
\hline 1. & Sikap Ketertarikan & 3 & $27,3 \%$ \\
2. & Sikap Keinginan & 3 & $27,3 \%$ \\
3. & Emosional & 1 & $9,10 \%$ \\
4. & Bermoral & 4 & $36,4 \%$ \\
\hline
\end{tabular}

Dari hasil penelitian yang meneliti aspek karakter tokoh Aira pada novel Pada Senja yang Membawamu Pergi karya Boy Candra, terdapat karakter tokoh Aira yang baik untuk diterapkan pada siswa yaitu sikap moral yang baik pada Aira disaat dia sedang merasakan jatuh cinta pada seorang lelaki bersamaan dengan itu Aira harus pergi meninggalkan pujaan hatinya karena dia harus mengambil beasiswa ke Jepang yang sudah jauh hari diimpikannya. Artinya Aira mempunyai pemahaman tentang cinta yang berbeda dengan orang lain, Aira mampu konsisten dengan apa 
yang sudah diimpikannya dari pada harus menjalin cinta yang masih belum jelas karena Aira percaya jika dia beneran cinta pasti dia tidak keberatan untuk menunggunya kembali pulang.

\section{KESIMPULAN}

Berdasarkan hasil dari penelitian yang sudah dianalisis, untuk itu peneliti dapat mengambil kesimpulan bahwa, tokoh dan penokohan dalam novel Pada Senja yang Membawamu Pergi karya Boy Candra adalah Aira. Peneliti menelaah karakter tokoh Aira berdasarkan sikap ketertarikan, keinginan, emosional dan bermoral yang terdapat pada Aira melalui dialog langsung maupun kalimat yang diucapkan oleh tokoh lain tentang karakter Aira. Terdapat tiga karakter dari sikap ketertarikan yaitu mencintai Gian, menyukai pakaian berwarna hitam atau berunuansa gelap, dan menyukai senja. Kemudian dari sikap keinginan terdapat tiga karakter yaitu ingin mendapatkan beasiswa ke Jepang, berdamai dengan masa lalu, dan ingin menjalani hidup bersama Gian. Dari sikap emosional terdapat satu karakter yaitu masih terbayang masa lalunya. Terakhir dari sikap bermoral yaitu dewasa dalam menyikapi suatu hal, wanita yang cerdas, sopan dan baik hati, selalu menghargai orang lain, dan peduli dengan perasaan Neneknya.

Implikasi terhadap pembelajaran sastra di SMA pada tokoh Aira dalam novel Pada Senja yang Membawamu Pergi karya boy Candra memiliki nilai moral yang baik untuk diterapkan pada siswa yaitu tokoh Aira pada novel tersebut memiliki sikap yang konsisten dan bijak dalam mengambil suatu keputusan dihidupnya. Artinya disaat wanita lain mengutamakan persoalan percintaanya dibanding untuk mengutamakan pedidikannya, diwaktu yang bersamaan dia baru saja menemukan pujaan hatinya. Namun, dia lebih memilih untuk melanjutkan pendidikannya yang didapat melalui beasiswa ke Jepang karena sudah sejak lama dia memimpikan untuk mendapatkan beasiswa tersebut.

\section{REKOMENDASI}

Berdasarkan hasil penelitian yang telah dipaparkan, menurut saya penelitian dengan memilih objeknya adalah novel merupakan pilihan yang tepat. Karena dapat dianalisis kapan saja dan di mana saja, novel dapat menjadi referensi untuk bahan penelitian skripsinya. Di dalam novel terdapat banyak sekali unsur intrinsik dan ekstrinsik yang bisa dijadikan sebagai bahan untuk penelitian skripsi.

\section{UCAPAN TERIMAKASIH}

Terimakasih saya ucapkan kepada ibu dan bapak saya yang selalu memberikan semangat dan membantu memberikan dana dalam menyelesaikan skripsi ini. Tidak lupa juga saya ucapkan terimakasih kepada teman saya yang bernama syifa dan alfi yang selalu memberikan semangat untuk menyelesaikan skripsi ini, mereka juga yang telah merekomendasikan jurnal Unigal sebagai wadah untuk mempublikasikan artikel saya.

\section{DAFTAR PUSTAKA}

Candra, B. (2018). Pada Senja yang Membawamu Pergi. GagasMedia.

Moleong, L. J. (2004). Metode Penelitian Kualitatif. Bandung: Remaja Rosda Karya.

Sudjiman. (1986). Kamus Istilah Sastra. Jakarta: PT. Gramedia Pustaka Utama.

Sugiyono. (2012). Metode Penelitian Kuantitatif, Kualitatif, dan R\&D. Bandung: Alfabeta.

Suharianto, S. (2009). Menuju pembelajaran sastra yang apresiatif. Semarang: penerbit bandungan institut.

Teeuw. (2013). Sastra dan Ilmu Sastra Pengantar Teori Sastra. Bandung: Pustaka Jaya.

Wellek, R., \& Warren, A. (1989). Teori Kesusastraan, terj. Melani Budianta. Jakarta: Gramedia. 